\title{
PRELIMINARY MONITORING OF PHYSICO-CHEMICAL PARAMETERS OF WATER WELLS FROM THE VILLAGE OF BIVOLARI (THE MOLDAVIAN PLAIN)
}

\author{
Nepotu Grigore ${ }^{1}$, Gheorghe Romanescu ${ }^{1}$, Cristian Constantin Stoleriu ${ }^{1}$
}

Key words: dissolved oxygen, electrical conductivity, $\mathrm{pH}$, resource, water quality

\begin{abstract}
The main objective of the paper is focused on water quality research in the village of Bivolari, Iasi County. The Bivolari settlement is situated in the Prut meadow and develops along the road connecting Iasi and Stefanesti. The research done in this paper starts from the collection of data on water $\mathrm{pH}$, water LDO (oxygen concentration), $\mathrm{CDC}$ (dissolved salt content) and water temperature. The parameters were measured for 7 months using the HACH-LANGE multiparameter of the Geoarchaeology Laboratory at Alexandru Ioan Cuza University of Iasi (Inter-disciplinary Platform ArheoInvest). The study is structured in two sections: scientific substantiation and applicative research. The scientific substantiation part analyzes the water features in the context of the integrated management approach as well as an analysis of the quality aspects of the water supply. The applied research part required monthly field measurements in 50 fountains (without the winter season). The approached subject is is complex and up-to-date because the citizen is a priority for EU Member States (EUPAN, 2009): the aspect of "customer satisfaction" represents a capital priority. Finally, the database is structured into two categories: spatial information such as maps; tabular information attached to spatial data. The paper also follows the transition from the field of research into the field of application by presenting models of data representation, which are at the same time tools adapted to the practical needs. In order to achieve this goal, the concept of quality (both in terms of product drinking water and local consumer) is defined and addressed in an integrated manner. Of the 50 wells monitored, only one had a water shortage in the last 10 years, and in two other cases there were problems with household waste and dead animals that damaged the water supply. Some fountains can dry at intervals of 3-4 years.
\end{abstract}

\footnotetext{
${ }^{1}$ Department of Geography, Faculty of Geography and Geology, "Alexandru Ioan Cuza" University of Iasi, Romania. Corresponding author: romanescugheorghe@gmail.com
} 


\section{Introduction}

The fundamental part of the paper includes an analysis and evaluation of the water features in the context of the integrated approach to water management. In the current context of water resource management, an analysis of the qualitative aspects is strictly necessary. For this reason, underground water resources are highly researched internationally (Abiodun et al., 2016; Arduino et al., 2012; Di Palma et al., 2014; Halder and Islam, 2015; Kilungo et al., 2018; Kowalska et al., 2018; Lapworth et al., 2017; Maran et al., 2016; Merecki et al., 2015; Olabisi et al., 2008; Owa, 2014; Rozell and Reaven, 2012; Salihou et al., 2018; Sedrati et al., 2017, 2018; Yousefi et al., 2009; Zeng et al., 2018) but also national (Apostu et al., 2018; Briciu et al., 2016a,b; Burtea et al., 2015a,b; Chirica et al., 2018; Cical et al.,

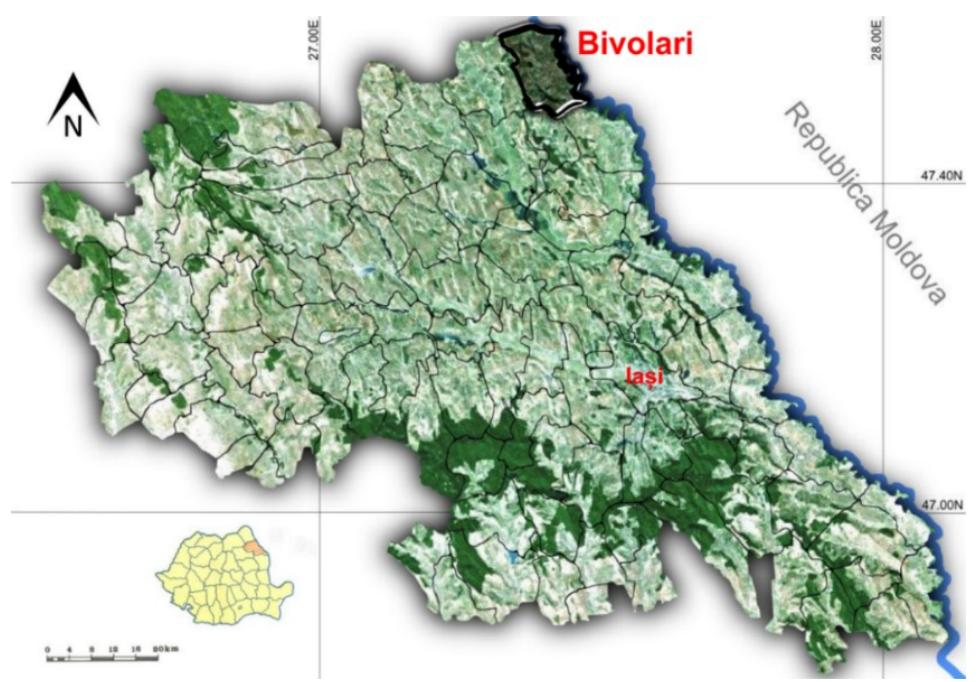

Fig.1. Geographical position of Bivolari in Iasi County and Romania

2016; Cirtina and Capatina, 2017a,b; Iordache et al., 2015; Mihai, 2018; Omer, 2016; Pantea et al., 2017; Papadatu et al., 2016; Patroescu et al., 2015, 2016a,b; Popescu et al., 2015; Romanescu et al., 2013, 2014a,b,c, 2015a,b,c; Stefan et al., 2017; Ungureanu et al., 2017). For the national part, research on the water in the wells is important because more than $50 \%$ of the rural population is powered exclusively from the groundwater (Chirica et al., 2018, Cical et al., 2016, Cirtina and Capatina, 2017a,b.).

Research undertaken in areas with water quality problems analyzes in detail all physico-chemical components. The influences of nitrates, nitrites, phosphates, mercury, etc. are highlighted on human health. As pollution sources, for most fountains in Romania, there are not industrial units, but toilets without septic tanks 
and the discharge of household wastes into unprocessed spaces. From this point of view Moldova is totally uncovered. Over $80 \%$ of wells in Moldavian Plateau are polluted and banned for human consumption. However, the population still feeds from these sources. The study aims to analyze groundwater in the Bivolari village fountains in order to determine the value of the resource and its quality.

\section{Study area}

The village of Bivolari is the residence of the commune with the same name. He has the third rank under Law no. 351/2001 regarding the approval of the National Territory Planning Plan - Section IV of the "Localities Network". It is crossed by the parallel $47^{\circ} 31^{\prime} 18^{\prime \prime} \mathrm{N}$ and the meridian of $27^{\circ} 26^{\prime} 55^{\prime \prime} \mathrm{E}$.

The village is located on the right bank of the Prut River, in the north-eastern extremity of Iasi County, on the border with Botosani County and on the border with the Falesti rayon in Moldova. It is located entirely in the Prut's major river bed and is protected by the longitudinal dykes that accompany its course. The drainage systems (channels) are rectangular.

\section{Methodology}

The samples were collected in conformity with the manual of water quality monitoring system elaborated by the specialists of the National Institute of

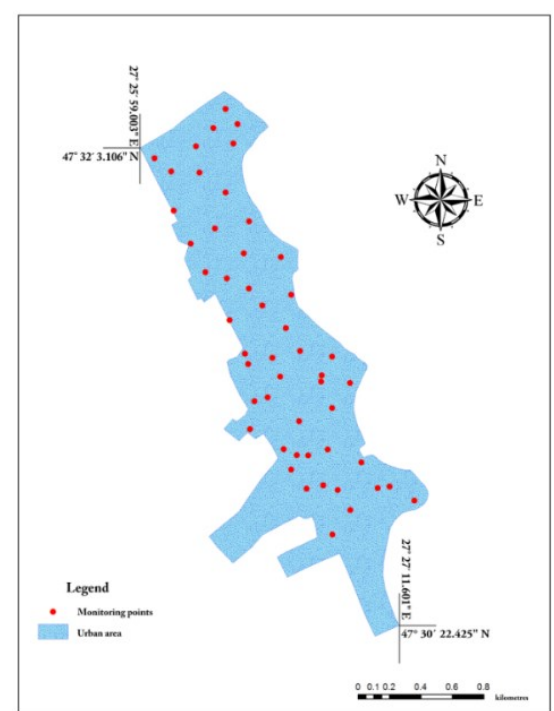

Fig.2 Location of physical-chemical parameter monitoring points

Hydrology and Water Management in Bucharest. The chemical and biological analyses were conducted in the Geoarchaeology Laboratory within the Faculty of 
Geography and Geology Iasi and within the CERNESIM Laboratory of Alexandru Ioan Cuza University in Iasi. For expeditionary measurements HACH Drel/2010 multi-parameter was used. Through the devising of management plans for each atachment, in agreement with the EC Water Framework Directive 2000/60.

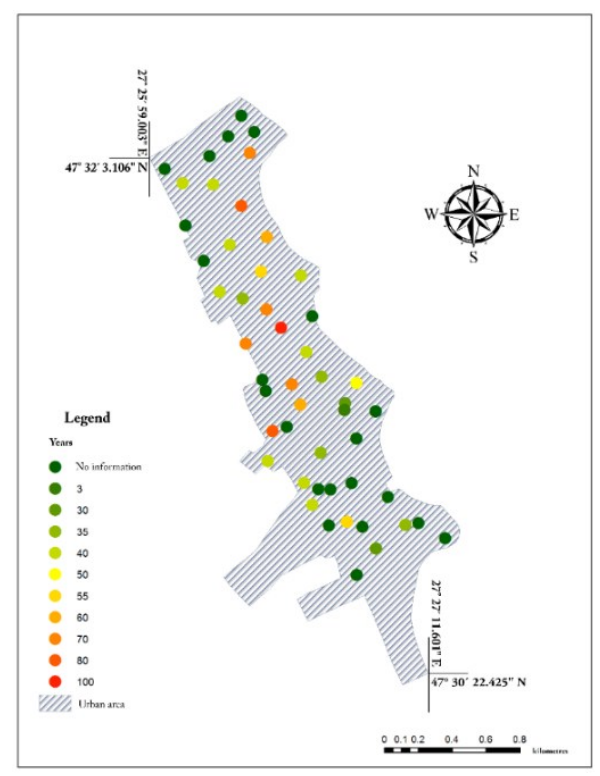

Fig. 3 The age of the wells in Bivolari

The maps were made in raster format that characterize morphometry (MNT) by processing 1:5000 topographical plans that were imported into SIG softwear, TntMips 6.9. The maps were georeferenced in the Stereo 1970 coordinate system. Starting from this information a vector layer of the level curves having georeference points transferred from the digital topographic support was made. After each monitoring, the database was introduced into Microsoft Excel for processing. The ArcMap 10.2.2 software was used to produce final maps (Ashour et al., 2017; Langovici and Dedjanski, 2017; Romanescu et al., 2016a,b,c, 2017). The advantages of using SIG methods are related to the quantitative and qualitative processing of spatial data, their deciphering of space distribution and the identification of new information with practical applicability.

All active wells in the village were analyzed (50). These include the whole intravilan (Fig. 2). Some fountains have been older than 100 years but have been reactivated (Fig. 3). The monitoring was preliminary due to the fact that the cold period of the season was not included, being analyzed only 2 months of spring, 3 months of summer and 2 months of autumn. An increased attention is for the summer situation, when the majority of rural localities in Romania are facing a 
decrease or even a lack of water, especially of the underground. In summer many of the wells in Moldova are completely dry (Vaslui, Iasi, northern Galati county, etc.). Therefore, the analysis is only focused on the summer months.

The configuration of a water quality monitoring system from any drinking water source, which has the role of water quality monitoring and malfunction alerts, must be designed to detect any type of new pollutant that could endanger the safety of the water quality or treatment process. The main physical-chemical quality indicators analyzed in the water of the Bivolari village were temperature, $\mathrm{pH}$, electrical conductivity and dissolved oxygen. In addition to this parameter measurements were made for the level and thickness of the water layer (Kilungo et al., 2018, Kowalska et al., 2018, Lapworth et al., 2017).

\section{Results and discussions}

The subject is complex and topical, and the citizen is currently the most important (if not the only) priority of the EU Member States (EUPAN $\left.{ }^{2}, 2009\right)$.The aspect of "customer satisfaction" is an important priority of any civilized state (Sedrati et al., 2017, 2018). Monitoring of water sources for population supply and assessment of their impacts on water quality (based on information on salt content, dissolved oxygen and $\mathrm{pH}$ ) as well as the results obtained from the preliminary analysis of these properties resulted in emphasizes the need to analyze more and more elaborate matrices for knowledge of the entire toxic and dangerous complex of existing substances in water. For water to be drinkable, they must be completely eliminated through a treatment process.

The isobaths of all fountains exceed $11 \mathrm{~m}$. The lowest depths are found in the central part of the village, in the middle of the meadow. The largest ones are on the first terrace in the south of the locality (Fig. 4). Decreased levels in the summer are due to the low flow of the Prut River (Corduneanu et al., 2016, Diaconu et al., 2017, Romanescu and Cojocaru, 2010, Romanescu and Stoleriu, 2014). The largest depth is $19 \mathrm{~m}$ and is located in the southwest part of the village, on the terrace. The smallest depth is $11.5 \mathrm{~m}$ and is in the sector of a deserted watercourse.

${ }^{2}$ EUPAN is an informal network where officials from all EU countries cooperate and exchange information in the field of public administration. 


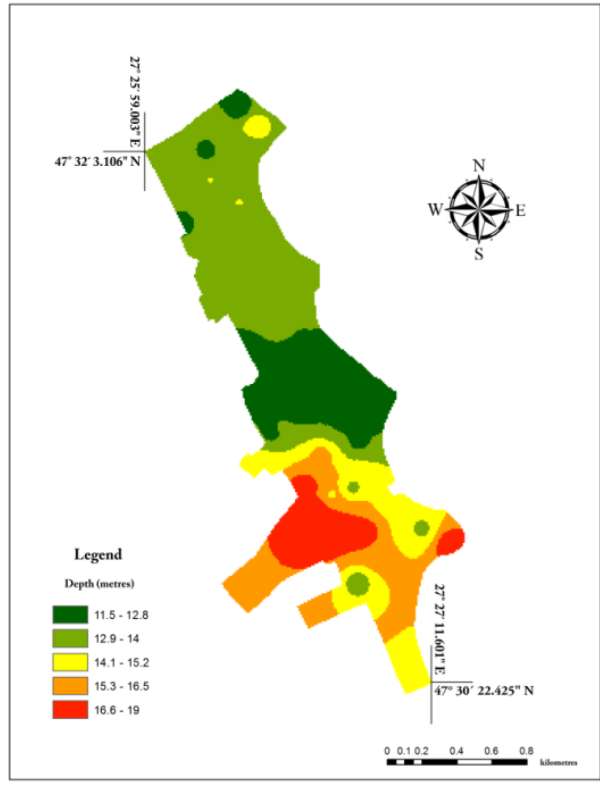

Fig. 4 Depth to water surfaces of fountains (isobaths)

Samples were collected from 50 wells. Most (19) have body water thicknesses of about $3 \mathrm{~m}(38 \%)$. Those with $1 \mathrm{~m}$ and $2 \mathrm{~m}$ thickness represent $6 \%$ and $12 \%$ (Fig 6). 28 fountains have body water densities up to $3 \mathrm{~m} \mathrm{(56 \% ).} \mathrm{Those} \mathrm{with} \mathrm{a} \mathrm{thickness}$ of $5 \mathrm{~m}, 6 \mathrm{~m}$ and $7 \mathrm{~m}$ represent $44 \%$.

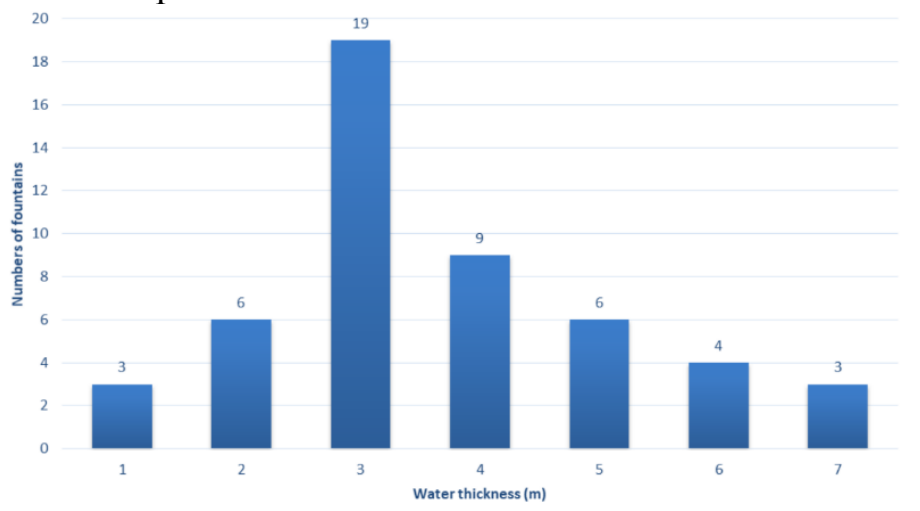

Fig. 5 Number of fountains depending on the thickness of the water body 


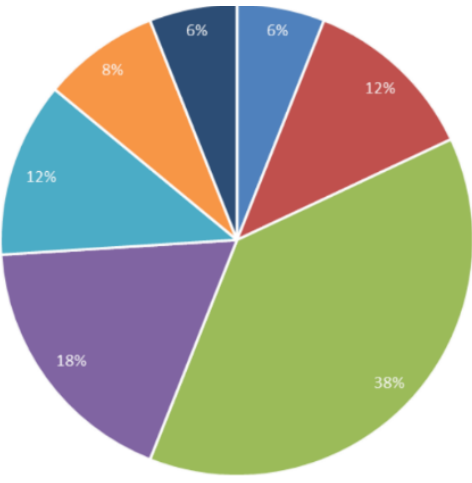

Water thickness $(\mathrm{m})=1=2=3=4=5=6=7$

Fig. 6 The water body thickness in the 50 wells in percentage expression

The largest thicknesses of the water layer overlap over the meadow areas where the isobath is lower. The smallest thicknesses of the water layer appear in the sector of the first terraced area where the isobaths have higher values (Fig 7). The maximum water layer is $7 \mathrm{~m}$, indicating a significant amount of water. The smallest thickness of the water layer is $1 \mathrm{~m}$ and corresponds to the meadow sector with low clayey substrate and isobaths.

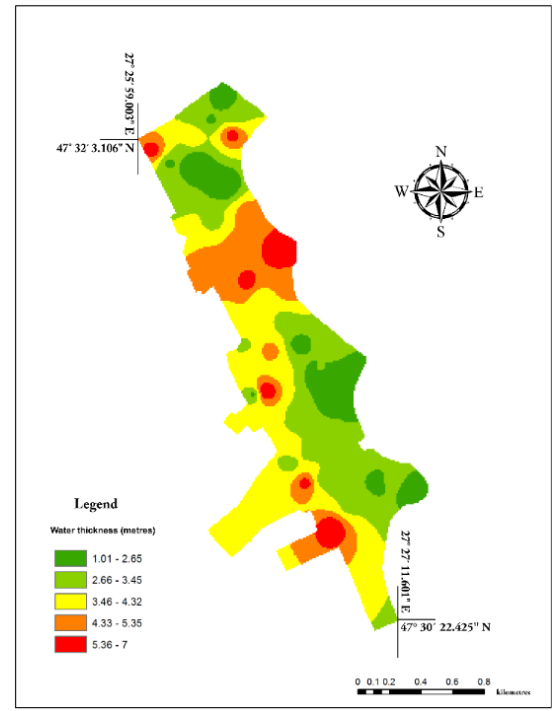

Fig. 7 Thickness of water in fountains

July is the fourth month under review and the second monitored summer month. The temperatures recorded during this period are characteristic of the 
season: the average air temperature on the day of monitoring was $23.9^{\circ} \mathrm{C}$ (Fig 8). The maximum was recorded at 12 o'clock and was $26.5^{\circ} \mathrm{C}$ and the minimum at 19 $\left(19.4^{\circ} \mathrm{C}\right)$. In contrast, water in the groundwater had a minimum of $11.6^{\circ} \mathrm{C}$ and a maximum of $16.5^{\circ} \mathrm{C}$. The average temperature of the fountain fountains was $14.1^{\circ} \mathrm{C}$ (Fig 9). The difference between the average air temperature and the ground temperature is $9.8^{\circ} \mathrm{C}$.

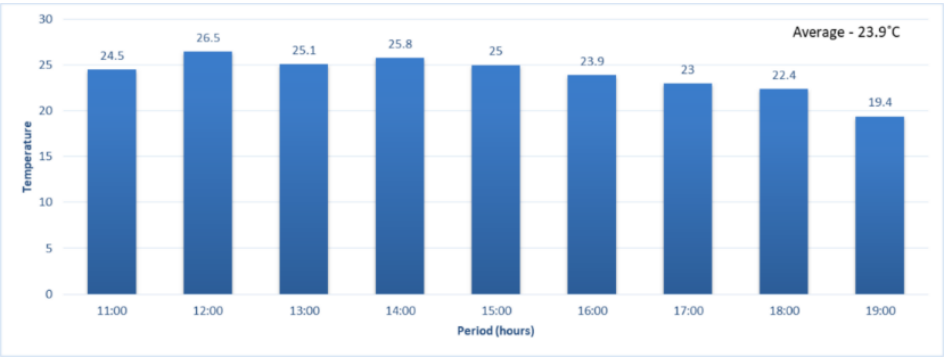

Fig. 8 Air temperature during sampling $\left({ }^{\circ} \mathrm{C}\right)$

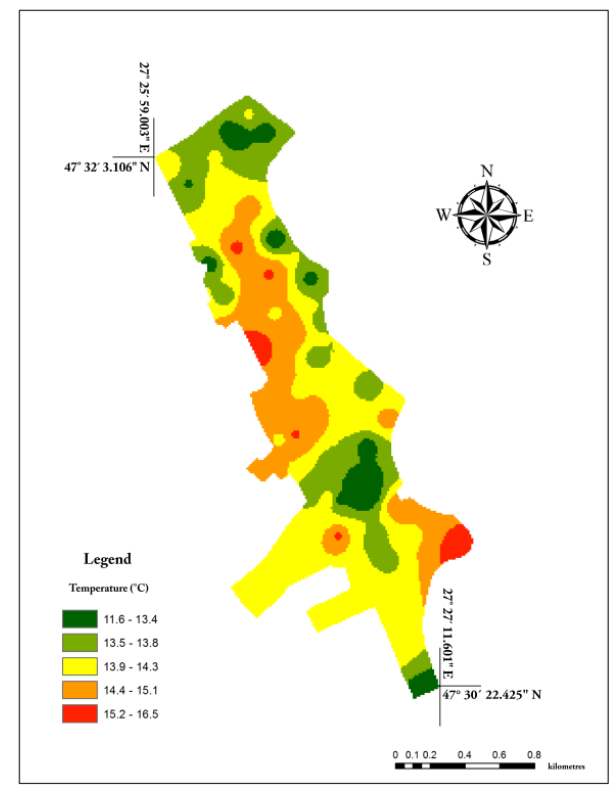

Fig. 9 Average water temperature in July

No thermal abnormalities are recorded, but the difference between air and substrate is obvious and this factor makes groundwater better than the surface. The earth usually keeps water from the wells at a relatively constant temperature of between $11^{\circ} \mathrm{C}$ and $15^{\circ} \mathrm{C}$. At $4^{\circ} \mathrm{C}$ the water has the lowest volume and the highest 
density which allows the existence of aquatic life also in winter. Also, water can be stored and then can yield heat (Apostol, 1988, 2008; Barbulescu, 2015; MihuPintilie et al., 2014).

The most important period of the year for water supply in Moldova is in the summer. Due to the high temperatures and lack of rainfall the groundwater level and implicitly the flow of all rivers decreases (Romanescu et al., 2017). However, the water resource in the Prut meadow is sufficient for the population of the village of Bivolari.

The temperature in the water body of the wells is maintained during summer at values between $8^{\circ} \mathrm{C}-12^{\circ} \mathrm{C}$. At the surface of the water, depending on the area where the fountain was made and the level of water in which water is taken, the spring-summer semester temperature is between $11^{\circ} \mathrm{C}-15^{\circ} \mathrm{C}$ and in autumn-winter between $8^{\circ} \mathrm{C}-13^{\circ} \mathrm{C}$. All chemical parameters at depths greater than $2 \mathrm{~m}$ in the body of water are kept constant and the differences are extremely small. Because of this, they are no longer represented graphically.

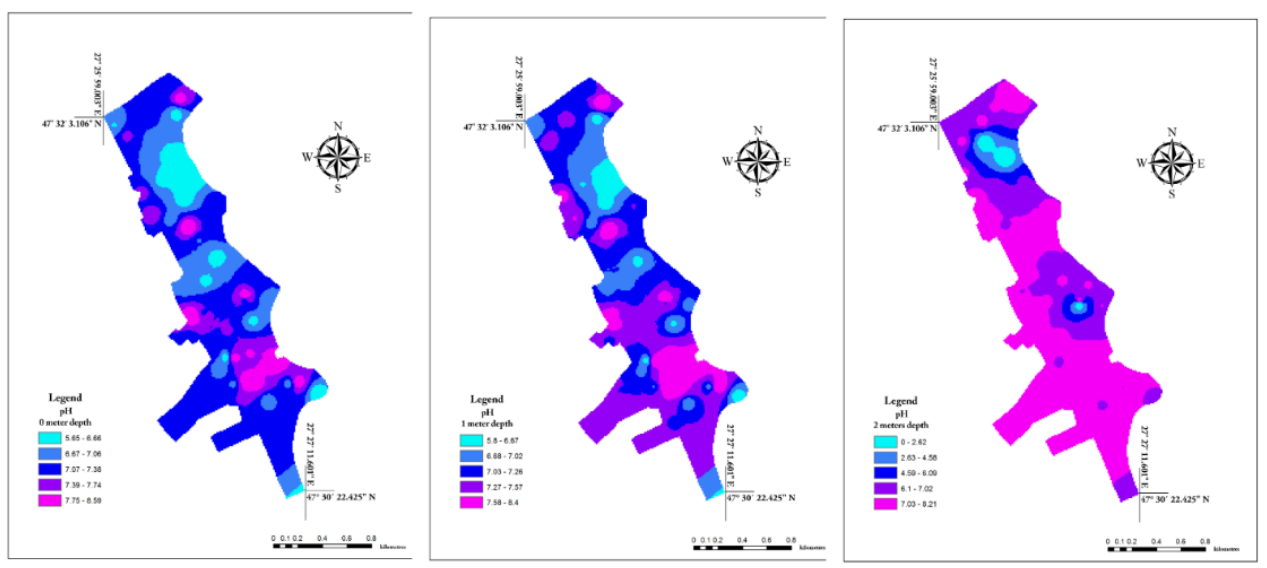

Fig. $10 \mathrm{pH}$ values at $0 \mathrm{~m}, 1 \mathrm{~m}$ and $2 \mathrm{~m}$.

If we talk about $\mathrm{pH}$, the pattern in the spring months continues when the values indicate a neutrality $(\mathrm{pH} 7)$. The water layer in the groundwater continues to be neutral to the base, with an $80 \%$ water scatter and a depth of $1 \mathrm{~m}$. At depths over $1 \mathrm{~m}$ the $\mathrm{pH}$ is alkaline $(\mathrm{pH} 7-8.21)$ at $90 \%$. Acidic waters are located in the northeastern extremity of the village, in the Prut River's own meadow, near animal farms (Fig 10).

The $\mathrm{pH}$ value for the entire body of water indicates the presence of mild waters with values ranging from $7-8.2 \mathrm{pH}$ has a strong impact on water toxicity phenomena. A low value leads to increased toxicity of nitrites and heavy metals in water. A high $\mathrm{pH}$ increases ammonia toxicity. Low $\mathrm{pH}$ occurs frequently in spring, 
with snow melting, especially in areas with permeable soils where water filtration is possible (Romanescu and Stoleriu, 2014).
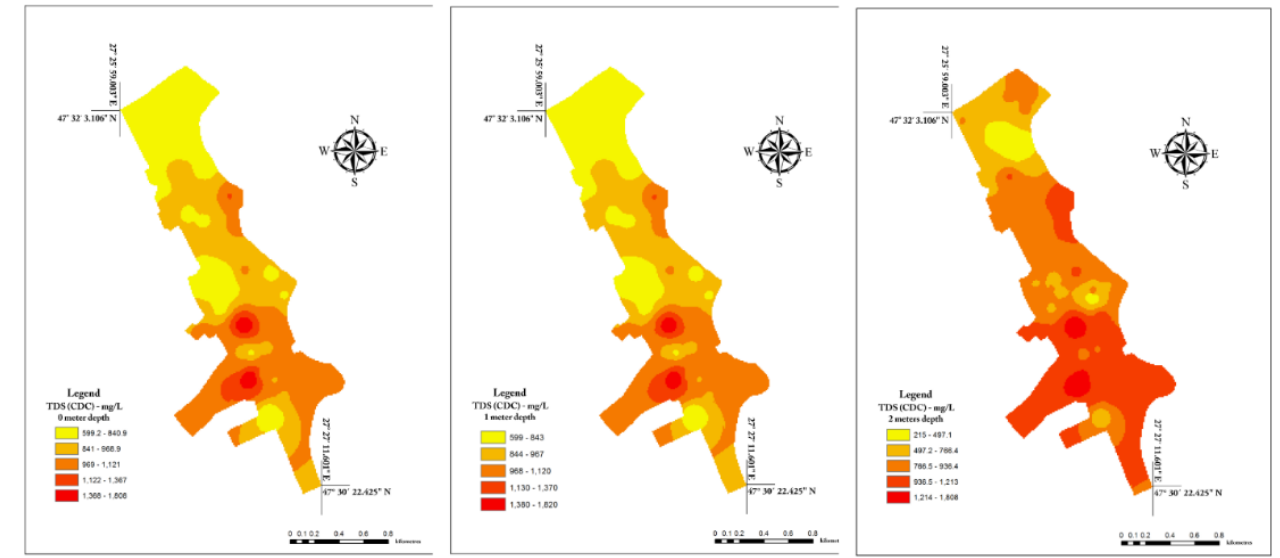

Fig.11 Electrical conductivity (CDC) values at $0 \mathrm{~m}, 1 \mathrm{~m}$ and $2 \mathrm{~m}$

July Electricity Conductivity (CDC) has a minimum of $215 \mathrm{mg} / \mathrm{L}$ and a maximum of $1820 \mathrm{mg} / \mathrm{L}$. For low-water waters (up to $1 \mathrm{~m}$ ) there is low conductivity. The distribution of values gradually increases from north to south. The highest values are recorded at depths over $1 \mathrm{~m}$. A high conductivity value reveals the existence of larger amounts of dissolved salts. High values are recorded in the southern sector, with $>900 \mathrm{mg} / \mathrm{L}$ at the surface of the water and $>940 \mathrm{mg} / \mathrm{L}$ at depths of $>1 \mathrm{~m}$ (Fig 11).

The value of electrical conductivity is the physical size that characterizes the capacity of a material to allow the transport of electrical loads when placed in an electric field. In this case it is given by the content of dissolved salts. Some effects that lead to salt changes in water are: geological events that can increase the salt concentration in groundwater; natural factors that can channel groundwater rich in salts to the surface (Romanescu, 2003, 2006; Romanescu and Stoleriu, 2014).

Dissolved oxygen (LDO) in the summer months is directly proportional to electrical conductivity (CDC). The minimum and maximum values of dissolved oxygen are between $0-9.45 \mathrm{mg} / \mathrm{L}$. Value 0 occurs in wells with a very low water body thickness. High values are recorded in the cold season and relatively low in the warm season. Areas with the highest values of dissolved oxygen are located at depths of over $1 \mathrm{~m}$ and in the southern sector of the commune where zootechnical farms are missing. The lateral springs have a large amount of oxygen dissolved in the whole water body (the southern sector) (Fig 12). 
Another factor with a special influence on the oxygen content in water is also the amount of organic substances. Low values of oxygen content are due to the presence of large amounts of organic substances consumed in transformation processes (Romanescu and Stoleriu, 2014). From this point of view, pollution sources are represented by toilets without septic tanks, industrial and domestic livestock farms.
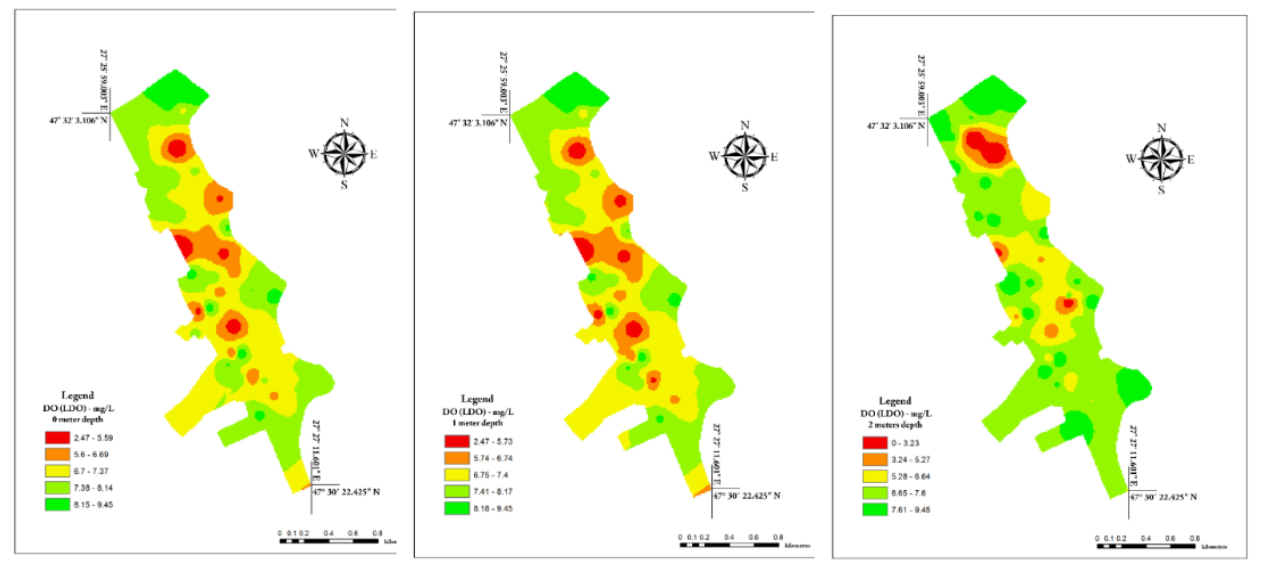

Fig. 12 Dissolved oxygen values (LDO) at la $0 \mathrm{~m}, 1 \mathrm{~m}$ and $2 \mathrm{~m}$

In the summer months there is a relatively uniform distribution of all values. Acidic waters occupy a very small proportion. Depending on the quality parameters analyzed, the water in the phreatic area of the monitored area is in the first quality class. In order to reduce the harmful effects of water quality in the village of Bivolari, it is necessary to know and to prevent them through an efficient monitoring system. Models and prognoses of quality evolution are required and ecological education of locals is required (Romanescu, 2003, 2006; Romanescu and Stoleriu, 2014).

Water quality can be defined as a conventional set of physical, chemical, biological and bacteriological characteristics, expressed in terms of value, which allow the sample to be grouped into a particular category, thereby acquiring the ability to serve a particular purpose. To determine the quality of the water (from the many physical, chemical and biological characteristics that can be determined by laboratory analysis), a limited number of characteristics are considered to be significant. The World Environmental Surveillance System provides for the monitoring of water quality through three categories of parameters: 

colibacilli;

- basic parameters: temperature, $\mathrm{pH}$, conductivity, dissolved oxygen,

- parametric indicators of persistent pollution: cadmium, mercury, organohalogenated compounds and mineral oils;

Optional parameters: total organic carbon, biochemical oxygen demand, anionic detergents, heavy metals, arsenic, boron, sodium, cyanides, total oils, streptococci. In order to assess the quality of water, based on the analysis report drawn up, it is necessary to detail the main features of the water (Di Palmaa et al., 2014, Diaconu et al., 2016).

\section{Conclusions}

The underground water is under the powerful influence of the Prut River. For this reason, underground traffic is rapid and pollution sources (especially toilets) have little influence. Out of the 50 monitored fountains only one had a severe water shortage in the last 10 years. In two other cases there were problems with household waste or dead animals that damaged the water supply. The resources are affected, by decreasing the level and implicitly the thickness of the body of water once every 3-4 years (dry years). From a physico-chemical point of view, the waters are of good quality and only permanent monitoring of the main parameters is recommended.

Acknoledgments: Our thanks go to the Geoarchaeology Laboratory within the Faculty of Geography and Geology, "Alexandru Ioan Cuza" University of Iasi (Romania), which provided the tools and carried out the processing of the data. This work was made possible by the financial support of the Ministry of National Education (Exploratory research project PN-III-P4-ID-PCE-2016-0759, the Ethnoarchaeology Salt in the Inner Carpathian Area of Romania, no 151/2017).

\section{References}

Abiodun A.S., Temilade E.O., Oladimeji F.N., Tawakalit F.T. 2016, Assessment of water contamination in Nigeria-review. Journal of Basic and Applied Research International, 19(1):62-76.

Apostol L. 1988, Anomalii ale temperaturii aerului pe teritoriul Moldovei. Lucr. Semin. Geogr. "Dimitrie Cantemir", 9:101-109.

Apostol L. 2008, The mediterranean cyclones - the role in ensuring water resources and their potential of climatic risk, in the east of Romania. Present Environment and Sustainable Development, 2:143-163.

Apostu M., Tantaru G., Vieriu M., Bibire N., Panainte A.D. 2018, Study of the presence of lead in a series of foods of plant origin. Rev.Chim.(Bucharest), 69(5):1223-1225. 
Arduino S., Colombo G., Ocampo O.M., Panzeri L. 2012, Contamination of Community Potable Water from Land Grabbing: A Case Study from Rural Tanzania. Water Alternatives, 5(2):344-359.

Ashour M., Aly T., Eldegwee Y. 2017, An Investigation Concerning the Impact of Climate Changes on the Water Equilibrium in the Egyptian Nile Delta. Annals of Valahia University of Targoviste, Geographical Series, 17(1):58-69. Doi:10.1515/avutgs2017-0006.

Barbulescu A. 2015, Modeling temperature evaluation. Case study. Romanian Reports in Physics, 68(2):788-798.

Briciu A.E., Toader E., Romanescu G., Sandu I. 2016a, Urban Streamwater contamination and Self-purification in a Central-Eastern European City. Part I. Rev. Chim. (Bucharest), 67(7):1294-1300.

Briciu A.E., Toader E., Romanescu G., Sandu I. 2016b, Urban Streamwater Contamination and Self-purification in a Central-Eastern European City - Part B. Rev. Chim. (Bucharest), 67(8):1583-1586

Burtea M.C., Sandu I.G., Cioromele G.A., Bordei M., Ciurea A., Romanescu G. 2015a, Sustainable Exploitation of Ecosystems on the Big Island of Braila. Rev. Chim. (Bucharest), 66(5):621-627.

Burtea M.C., Ciurea A., Bordei M., Romanescu G., Sandu A.V. 2015b, Development of the Potential of Ecological Agriculture in the Village Ciresu, County of Braila. Rev. Chim. (Bucharest), 66(8):1222-1226.

Chirica S, Luca A-L, Lates I. 2018, Considerations on drinking water management in the Moldavian plateau and plain region. PESD, 12(1):139-147.

Cical E., Mihali C., Mecea M., Dumuta A., Dippong T. 2016, Considerations on the relative efficacy of aluminium sulphates versus polyaluminium chloride for improving drinking water quality. Studia Universitatis Babes-Bolyai, Chemia, 61(2):225-238.

Cirtina D., Capatina C. 2017a, Preliminary Study on Assessment of Mineralization Degree and Nutrient Content of Groundwater Bodies in Gorj County. Rev. Chim.(Bucharest), 68(2):221-225.

Cirtina D., Capatina C. 2017b, Assessment of Drinking Water Quality of Targu Jiu City by Analyzing Physical and Chemical Quality Parameters. Rev.Chim.(Bucharest), 68(3):439-446.

Corduneanu F., Vintu V., Balan I., Crenganis L., Bucure D. 2016, Impact of drought on water resources in north-eastern Romania. Case study - the Prut River. Environmental Engineering \& Management Journal (EEMJ), 15(16):1213-1222.

Di Palma P.R., Romano E., Corazza A., Duro A., Campopiano F., Vacca G., Preziosi E. 2014, Best practices protocol for drinking water supply contamination emergencies. Procedia Engineering, 70:535 - 544.

Diaconu D.C., Peptenatu D., Simion A.G., Pintilii R.D., Draghici C.C., Teodorescu C.Grecu A., Gruia A.K., Ilie A.M. 2017, The restrictions imposed upon the urban development by the piezometric level. Case study: Otopeni-Tunari-Corbeanca. Urbanism. Architecture. Constructions, 8(1):27-36.

Halder J.N., Islam M.N. 2015, Water Pollution and its Impact on the Human Health. Journal of Environment and Human, 2(1): 2373-8332. 
Iordache M., Popescu L.R., Pascu L.F., Lehr C.,Ungureanu E.M., Iordache I. 2015, Evaluation of the Quality of Environmental Factors, Soil and Water in the Parang Mountains, Romania. Rev. Chim. (Bucharest), 66(7):1009-1014.

Kilungo A., Powers L., Arnold N., Whelan K., Paterson K., Young D. 2018, Evaluation of Well Designs to Improve Access to Safe and Clean Water in Rural Tanzania. Int. J. Environ. Res. Public Health, 15:64. Doi:10.3390/ijerph15010064.

Kowalska, J.B., Mazurek, R., Gąsiorek, M., Michał Gąsiorek, Tomasz Zaleski. 2018, Pollution indices as useful tools for the comprehensive evaluation of the degree of soil contamination-A review. Environmental Geochemistry and Health, 1-26. https://doi.org/10.1007/s10653-018-0106-z.

Langovic M., Dedjanski V. 2017, Water Supply in the Republic of Serbia - State and Perspectives. Annals of Valahia University of Targoviste, Geographical Series, 17(1):28-36. Doi:10.1515/avutgs-2017-0003.

Lapworth D.J., Nkhuwa D.C.W., Okotto-Okotto J., Pedley S., Stuart M.E., Tijani M.N., Wright J. 2017, Urban groundwater quality in sub-Saharan Africa: current status and implications for water security and public health. Hydrogeol J., 25:10931116.

Maran N.H., Crispim B.A, Iahnn S.R., Araújo R.P., Grisolia A.B., Oliveira K.M.P. 2016, Depth and Well Type Related to Groundwater Microbiological Contamination. Int J Environ Res Public Health., 13(10):1036.

Merecki N., Agič R., Šunić L., Milenković L., Ilić Z.S. 2015, Transfer factor as indicator of heavy metals content in plants. Fresenius Environmental Bulletin, 24(11c):42124219.

Mihai F-C. 2018, Rural plastic emissions into the largest mountain lake of the Eastern Carpathians. Royal Society Open Science, 5:172396.

Mihu-Pintilie A., Romanescu G., Stoleriu C. 2014, The seasonal changes of the temperature, $\mathrm{pH}$ and dissolved oxygen in the Cuejdel Lake, Romania. Carpathian Journal of Earth and Environmental Sciences, 9(2):113-123.

Olabisi O.E., Awonusi A.J., Adebayo O.J. 2008, Assessment of bacteria pollution of shallow well water in Abeokuta, Southwestern Nigeria. Life Science Journal, 5(1):5965.

Omer I. 2016, Water Quality Assesment of the Groundwater Body RODL01 from North Dobrogea. Rev.Chim.(Bucharest), 67(12):2405-2408.

Owa F.W. 2014, Water pollution: sources, effects, control and management. International Letters of Natural Sciences, 3:1-6.

Pantea I., Ferechide D., Barbilian A., Lupusoru M., Lupusoru G.E., Moga M., Vilcu M.E., Ionescu T., Brezean I. 2017, Drinking water quality assessment among rural areas suplied by a centralized water system in Brasov county. University Politehnica of Bucharest Scientific Bulletin, Series C-Electrical Engineering and Computer Science, Seria B, 79(1):61-70.

Papadatu C.P., Bordei M., Romanescu G., Sandu I. 2016, Researches on Heavy Metals Determination from Water and Soil in Galati County, Romania. Rev.Chim.(Bucharest), 67(9):1728-1733. 
Patroescu V., Jinescu C., Cosma C., Cristea I., Badescu V., Stefan C.S. 2015, Influence of Ammonium Ions on the Treatment Process Selection of Groundwater Supplies Intended to Human Consumption. Rev. Chim. (Bucharest), 66(4):537-541.

Patroescu V., Ionescu I., Tiron O., Bumbac C., Mares M.A., Jinescu G. 2016a, Nitrification Front Evolution in a Biological Filter Using Expanded Clay As a Filter Media. Rev. Chim. (Bucharest), 67(5):958-961.

Patroescu I.V., Dinu L.R., Constantin L.A., Alexie M., Jinescu G. 2016b, Impact of Temperature on Groundwater Nitrification in an Up-Flow Biological Aerated Filter Using Expanded Clay as Filter Media. Rev. Chim. (Bucharest), 67(8):1433-1435.

Popescu L.R., Iordache M., Buica G.O., Ungureanu E.M., Pascu L.F., Lehr C. 2015, Evolution of groundwater quality in the area of chemical platform. Rev.chim.(Bucharest), 66(12):2060-2064.

Romanescu G. 2003, Hidrologie generala. Editura TERRA NOSTRA, Iasi.

Romanescu G. 2006, Hidrologia uscatului. Editura Terra Nostra, Iasi.

Romanescu G., Cojocaru I. 2010, Hydrogeological considerations on the western sector of the Danube Delta - a case study for the Caraorman and Saraturile fluvial-marine levees (with similarities for the Letea levee). Environmental Engineering and Management Journal, 9(6):795-806.

Romanescu G., Cretu M.A., Sandu I.G., Paun E., Sandu I. 2013, Chemism of Streams Within the Siret and Prut Drainage Basins: Water Resources and Management. Rev. Chim. (Bucharest), 64(12):1416-1421.

Romanescu G., Stoleriu C. 2014, Seasonal Variation of Temperature, $p H$ and Dissolved Oxygen Concentration in Lake Rosu, Romania. CLEAN - Soil, Air, Water, 42(3):236242.

Romanescu G., Sandu I., Stoleriu C., Sandu I.G. 2014a, Water Resources in Romania and Their Quality in the Main Lacustrine Basins. Rev. Chim. (Bucharest), 65(3):344349 .

Romanescu G., Paun E., Sandu I., Jora I., Panaitescu E., Machidon O., Stoleriu C. 2014b, Quantitative and Qualitative Assessments of Groundwater into the Catchment of Vaslui River. Rev. Chim. (Bucharest), 65(4):401-410.

Romanescu G., Tarnovan A., Sandu I.G., Cojoc G.M., Dascalita D., Sandu I. 2014c, The Quality of Surface Waters in the Suha Hydrographic Basin (Oriental Carpathian Mountains). Rev. Chim. (Bucharest), 65(10):1168-1171.

Romanescu G., Cojoc G.M., Sandu I.G., Tirnovan A., Dascalita D., Sandu I. 2015, Pollution Sources and Water Quality in the Bistrita Catchment (Eastern Carpathians). Rev. Chim. (Bucharest), 66(6):855-863.

Romanescu G., Tirnovan A., Sandu I., Cojoc G.M., Breaban I.G., Mihu-Pintilie A. 2015a, Water Chemism Within the Settling Pond of Valea Straja and the Quality of the Suha Water Body (Eastern Carpathians). Rev. Chim. (Bucharest), 66(10):17001706.

Romanescu G., Curca R.G., Sandu I.G. 2015b, Salt deposits in the Romanian Subcarpathians - genesis, repartition and ethnomanagement. International Journal of Conservation Science, 6(3):261-269. 
Romanescu G., Zaharia C., Sandu A.V., Juravle D.T. 2015c, The annual and multiuannual variation of the minimum discharge in the Miletin catchment (Romania). An important issue of water conservation. International Journal of Conservation Science, 6(4):729-746.

Romanescu G., Iosub M., Sandu I., Minea I., Enea A., Dascalita D., Hapciuc O.E. 2016a, Spatio-temporal Analysis of the Water Quality of the Ozana River. Rev. Chim. (Bucharest), 67(1):42-47.

Romanescu G., Hapciuc O.E., Sandu I., Minea I., Dascalita D., Iosub M. 2016b, Quality indicators for Suceava river. Rev. Chim. (Bucharest), 67(2):245-249.

Romanescu G., Miftode D., Mihu-Pintilie A., Stoleriu C.C., Sandu I. 2016c, Water Quality Analysis in Mountain Freshwater: Poiana Uzului Reservoir in the Eastern Carpathians. Rev.Chim.(Bucharest), 67(11):2318-2326.

Romanescu G., Pascal M., Pintilie Mihu A., Stoleriu C.C., Sandu I., Moisii M. 2017, Water Quality Analysis in Wetlands Freshwater: Common Floodplain of Jijia-Prut Rivers. Rev.Chim.(Bucharest), 68(3):553-561.

Rozell D.J., Reaven S.J. 2012, Water Pollution Risk Associated with Natural Gas Extraction from the Marcellus Shale. Risk Analysis, 32(8):1381-1393.

Salihou Djari M.M., Stoleriu C.C., Saley M.B., Mihu-Pintilie A., Romanescu G. 2018, Groundwater quality analysis in warm semi-arid climate of ahel countries: Tillabéri region, Niger. Carpathian Journal of Earth and Environmental Sciences, 13(1):277290.

Sedrati A., Houha B., Romanescu G., Sandu I.G., Sandu I., Diaconu D.C. 2017, Impact of agriculture upon the chemical quality of groundwaters within the Saharian Atlas steppe. El-Meita (Khenchela-Algeria). Rev.Chim.(Bucharest), 68(2):420-423.

Sedrati A., Houha B., Romanescu G., Stoleriu C.C.. 2018, Hydro-geochemical and statistical characterization of groundwater in the south of Khenchela, el Meita area (northeastern Algeria). Carpathian Journal of Earth and Environmental Sciences, 13(2):333-342.

Stefan D.S., Neacsu N., Pincovschi I., Stefan M. 2017, Water Quality and Selfpurification Capacity Assessment of Snagov Lake. Rev.Chim.(Bucharest), 68(1):6064.

Ungureanu G., Ignat G., Leonte E., Costuleanu C.L., Stanciu N, Sandu I.G., Donosa D., Bejinariu C. 2017, Solid Waste Management on Romanian Households. Rev.Chim.(Bucharest), 68(12):2941-2947.

Yousefi Z., Ziaei Hezarjaribi H., Enayati A.A., Mohammadpoor R.A. 2009, Parasitic contamination of wells drinking water in Mazandaran province. Iran. J. Environ. Health. Sci. Eng., 6(4):241-246.

Zeng L., Zhou F., Zhang X., Qin J., Li H. 2018, Distribution of heavy metals in soils and vegetables and health risk assessment in the vicinity of three contaminated sites in Guangdong Province, China. Human and Ecological Risk Assessment: An International Journal. DOI:10.1080/10807039.2018.1431043. 